\title{
The Traditional Chinese Medicine Fufang Shatai Heji (STHJ) Enhances Immune Function in Cyclophosphamide-Treated Mice
}

\author{
Kai-Jian Fan, ${ }^{1,2}$ Yun-Wu Li, ${ }^{1}$ Jing Wu, ${ }^{1}$ Jun Li, ${ }^{3}$ Jun Zhang, ${ }^{4}$ Qi-Shan Wang, \\ Bing-Xin Xu, ${ }^{1}$ Qing Cai $\mathbb{D}^{5},{ }^{5}$ and Ting-Yu Wang $\mathbb{D}^{1}$ \\ ${ }^{1}$ Department of Pharmacy, Shanghai Ninth People's Hospital, School of Medicine, Shanghai Jiao Tong University, \\ Shanghai 200011, China \\ ${ }^{2}$ Department of Pharmacy, Mental Health Center, Chongming District, Shanghai 202150, China \\ ${ }^{3}$ Department of Orthopedic Surgery, Rush University Medical Center, Chicago, IL 60612, USA \\ ${ }^{4}$ Department of Internal Medicine, Division of Nephrology, University of California at Davis, Davis, CA 95616, USA \\ ${ }^{5}$ Department of Immunology and Rheumatology, Changhai Hospital, The Second Military Medical University, \\ Shanghai 200433, China
}

Correspondence should be addressed to Qing Cai; caiqing_2011@126.com and Ting-Yu Wang; drtywang@163.com

Received 9 October 2019; Revised 6 December 2019; Accepted 9 December 2019; Published 23 January 2020

Academic Editor: Jairo Kennup Bastos

Copyright (c) 2020 Kai-Jian Fan et al. This is an open access article distributed under the Creative Commons Attribution License, which permits unrestricted use, distribution, and reproduction in any medium, provided the original work is properly cited.

Fufang Shatai Heji (STHJ) is a mixture of traditional Chinese medicines, such as Radix Adenophorae, Radix Pseudostellariae, and Radix Astragali. STHJ is commonly used to treat diseases caused by low immune function, for example, Sjögren's syndrome (SS). The primary objective of this study was to assess the immunopotentiating effect of STHJ using an immunosuppressive mouse model receiving cyclophosphamide (CTX). Following CTX treatment, STHJ was administered by oral gavage for 30 consecutive days. The percentage of specific lymphocyte subpopulations in the spleen was measured by flow cytometry. Levels of inflammatory factors in serum were detected by enzyme-linked immunosorbent assays (ELISAs). The administration of STHJ significantly elevated thymus and spleen indices, increased $\mathrm{B}$ cell and natural killer (NK) cell activities, and decreased $\mathrm{CD} 8^{+} \mathrm{T}, \mathrm{CD} 8^{+} \mathrm{CD} 122^{+} \mathrm{T}$, $\mathrm{NKT}$, and $\gamma \delta \mathrm{T}$ cell activities in the CTX-treated mice. In addition, STHJ upregulated the expression of interleukin- (IL-) 2, IL-6, and tumor necrosis factor- $\alpha$ (TNF- $\alpha$ ) and downregulated IL-10 expression in CTX-treated mice. In conclusion, STHJ effectively remitted CTX-induced immunosuppression by modulating the balance of lymphocyte subsets and cytokines. Our results suggest STHJ treatment could be used as an effective therapeutic approach to improve immune function in patients with low immunity.

\section{Introduction}

Job-related pressures and environmental pollution have been identified as the leading causes of immune suppression in the working population. Reduced immune strength could increase the risk of infection leading to autoimmune diseases. A previous study found that significant changes in the population of immune cells, such as neutrophils, lymphocytes, and eosinophils, would result in an impaired immune system [1]. To meet the clinical need, it is necessary to develop novel treatment strategies to improve immune function.

Cyclophosphamide (CTX) is a chemotherapeutic drug primarily used to treat tumors. It has been shown to have strong immunosuppressive effects by decreasing the absolute number of $\mathrm{T}$ cells, circulating $\mathrm{B}$ cells and synthesis of IgG. A number of studies have shown that animals treated with CTX could be used as a suitable model of long-term immunosuppression to evaluate the immune enhancement effects of drugs [2]. Previous studies found significant changes in both cellular and humoral immunity in CTXinduced immunosuppressed mice with reduced $\mathrm{CD} 4^{+} / \mathrm{CD}^{+}$ $\mathrm{T}$ cell ratios and B cell numbers [3]. Several immune cell subsets, such as immunosuppressive $\mathrm{T}$ regulatory cells (Tregs) and natural killer T (NKT) cells, have recently been identified and have been shown to play important roles in maintaining the balance of immunity. Whether these 
immunosuppressive cell subsets are affected in CTX-induced immunosuppressed mice and whether drugs could improve immunity through regulating these cells need to be further investigated.

Traditional Chinese medicine (TCM) with low toxicity could be administered for long periods of time to treat chronic diseases with low immune activities. Fufang Shatai Heji (also known as SS syrup, STHJ) is a concentrated liquid obtained by secondary decoction of various Chinese herbal medicines. These Chinese herbal medicines mainly include Pseudostellaria heterophylla (Miq.) Pax, root (Radix Pseudostellariae); Adenophora tetraphylla (Thunb.) Fisch., root (Radix Adenophorae); Astragalus membranaceus (Fisch.) Bge., root (Radix Astragali); Ophiopogon japonicus (Thunb.) Ker Gawl., root (Radix Ophiopogonis); Dendrobium nobile Lindl., stem (Dendrobium nobile); Glycyrrhiza uralensis Fisch., and rhizome (Glycyrrhiza uralensis). Radix Pseudostellariae contains polysaccharides and amino acids and has antitumor and immune-enhancing effects [4]. Radix Adenophorae largely contains polysaccharides and coumarin, which regulates immune function and eliminates free radicals [5]. The main components of Radix Astragali are Astragalus polysaccharides and Baicalin. Among these components, Astragaloside IV has been shown to have immunomodulatory effects by regulation of the activity of protein tyrosine phosphatase CD45 [6]. STHJ has been effectively used in the clinic to improve the immunity of patients for more than 30 years. A number of clinical studies have also confirmed the immunomodulatory effects of STHJ $[7,8]$. Moreover, many published papers have demonstrated the immunomodulatory effects of ingredients of STHJ. Yang found that the extract of supercritical carbon dioxide from Radix Adenophorae significantly increased the absolute number of $\mathrm{CD}^{+} \mathrm{T}, \mathrm{CD}^{+} \mathrm{T}$, and $\mathrm{CD} 8^{+} \mathrm{T}$ cells in the peripheral blood of immunosuppressed mice, thereby producing a significant recovery effect on the peripheral immune system [9]. Wang et al. found that the extract of Radix Pseudostellariae has an obvious antagonistic effect on the low conversion of T and B lymphocytes and a decrease of the phagocytic function of leukocytes induced by CTX [10]. Shi et al. found that Astragalus polysaccharide can significantly increase the phagocytosis of peritoneal macrophages and the conversion rate of peripheral blood lymphocytes in immunosuppressed mice induced by CTX [11]. In a preliminary animal experiment, we found STHJ could regulate the immunity of mice (unpublished data).

In the present study, we investigated the effects of STHJ on immune function in CTX-treated immunosuppressed mice. Bailing capsule was used as the positive drug control because it is often used to improve immunity in the clinic. The ratio of lymphocyte subpopulations and the balance between inflammatory and anti-inflammatory factors were detected to investigate whether STHJ could serve as a potential therapeutic agent to improve immunity.

\section{Materials and Methods}

2.1. Animals. Balb/c mice (male, 18-22 g, 6-8 weeks old) were purchased from the Laboratory Animal Center of
Shanghai Ninth People's Hospital. The mice were kept in SPF facilities with pathogen-free conditions (temperature, $22^{\circ} \mathrm{C} \pm 2^{\circ} \mathrm{C}$; humidity, $55 \% \pm 5 \%$ ) with a $12 \mathrm{~h}$ light-dark cycle. The experimental protocol was approved by the Ethics Committee of the Ninth People's Hospital affiliated with the Shanghai Jiao Tong University School of Medicine.

2.2. Drugs and Reagents. STHJ was obtained from the Shanghai Ninth People's Hospital (Shanghai, China). Briefly, Radix Pseudostellariae $300 \mathrm{~g}$, Radix Adenophorae $120 \mathrm{~g}$, Radix Astragali 120 g, Radix Ophiopogonis 90 g, Dendrobium nobile $90 \mathrm{~g}$, and Glycyrrhiza Uralensis $30 \mathrm{~g}$ were combined and extracted by boiling with an eight times volume of water for 1.5 hours and then a six times volume of water for 1 hour. Each extract was collected after boiling and filtered. The two filtrates were combined and let stand for 12 hours. The filtrate was then concentrated to $1000 \mathrm{ml}$ as STHJ. Injectable cyclophosphamide (CTX) was purchased from Baxter Oncology $\mathrm{GmbH}$ (Halle, Germany). Bailing was used as the positive control and purchased from Huadong Medicine Co. Ltd (Hangzhou, China). Mouse anti-CD3e-APC, mouse anti-CD4-FITC, mouse anti-CD8a-PE, mouse anti-Foxp3$\mathrm{PE}$, mouse anti- $\gamma \delta$ T-FITC, mouse anti-CD45R-PE, mouse anti-CD49b-FITC, mouse anti-CD122-APC, Foxp3/transcription factor staining buffer set, and cell stimulation cocktail were purchased from eBioscience (San Diego, CA, USA). Mouse ELISA kits (TNF- $\alpha$, IL-2, IL-6, and IL-10) were purchased from Multi Sciences (Hangzhou, China).

2.3. Experimental Protocols. Sixty mice were randomly assigned into five groups of 12 mice. One group was used as the normal control group; the others were intraperitoneally injected with CTX $(80 \mathrm{mg} / \mathrm{kg} / \mathrm{d})$ for three consecutive days. From day 4, three groups of CTX-treated mice were infused by oral gavage once a day for 30 days as follows: low STHJ group $(10 \mathrm{ml} / \mathrm{kg}$, low dosage of STHJ), high STHJ group $(20 \mathrm{ml} / \mathrm{kg}$, high dosage of STHJ), and the Bailing group $(1.2 \mathrm{~g} / \mathrm{kg}$, Bailing). The mice in the CTX-induced model group were treated with PBS by the same way.

2.4. Analysis of Astragaloside IV in STHJ by Thin-Layer Chromatography (TLC). STHJ $(50 \mathrm{ml})$ was extracted three times with $50 \mathrm{ml}$ of water-saturated $n$-butanol; the $n$-butanol extracts were then combined. After which, the resulting extract was washed three times with $50 \mathrm{ml}$ ammonia water and three times with $50 \mathrm{ml}$ distilled water. The $n$-butanol extract was evaporated to dryness, and the residue was dissolved in methanol $(1 \mathrm{ml})$ to obtain the test solution. The Astragaloside IV reference substance (1 mg) was dissolved in methanol $(1 \mathrm{ml})$ to obtain the standard solution. A solution of chloroform-methanol-water (13:7:2) was mixed and placed at $10^{\circ} \mathrm{C}$; the lower layer solution was used as the developing solvent. According to the thin-layer chromatography method, $5 \mu \mathrm{l}$ of each of the standard solution and the test solution was placed on the same silica gel G thinlayer plate and placed in a chromatographic tank for development. At the end of expansion, the plate was removed 
from the tank and dried, then sprayed with $10 \%$ sulfuric acid ethanol solution, and heated at $105^{\circ} \mathrm{C}$ until the spots were visible.

2.5. Effect of Drugs on Spleen and Thymus Indices. At the end of the experiment at 30 days, all mice were anesthetized with an intraperitoneal injection of sodium pentobarbital (45 mg/ $\mathrm{kg}$ ). The anesthetized mice were weighed and then killed by cervical dislocation. The spleen and thymus were collected and weighed to calculate the spleen and thymus indices, which were calculated as follows: spleen index $(\%)=($ spleen weight/body weight $) \times 100 \%$ and thymus index $(\%)=$ (thymus weight/body weight) $\times 100 \%$.

2.6. Isolation of Splenocytes. The spleen was obtained from the mice sacrificed under aseptic conditions, washed with sterile PBS, and crushed to isolate the splenocytes. The splenocytes were passed through a 100-mesh filter to obtain a uniform cell suspension. The obtained cell suspension was centrifuged at $2000 \mathrm{rpm}$ for 5 minutes. The reclaimed splenocytes were resuspended in red blood cell lysis buffer for 5 minutes to remove red blood cells. After centrifugation, the splenocytes were resuspended in PBS and then filtered. The splenocyte suspension was obtained by resuspending again after centrifugation.

2.7. Determination of the Proportion of Lymphocyte Subsets in Splenocytes. For the determination of surface antigens, splenocytes were treated with three staining combinations. $100 \mu \mathrm{l}$ of the splenocyte suspension prepared above was incubated for 30 minutes at $4^{\circ} \mathrm{C}$ in the dark with the following: $1.25 \mu \mathrm{l}$ of $\mathrm{APC}-\mathrm{CD}^{+}, 0.5 \mu \mathrm{l}$ of FITC-CD4 ${ }^{+}$, and $1.25 \mu \mathrm{l}$ of $\mathrm{PE}-\mathrm{CD}^{+}$; or $1.25 \mu \mathrm{l}$ of $\mathrm{APC}-\mathrm{CD} 3^{+}, 1 \mu \mathrm{l}$ of FITC$\mathrm{CD} 49 \mathrm{~b}^{+}$, and $2.5 \mu \mathrm{l}$ of $\mathrm{PE}-\mathrm{CD} 45 \mathrm{R}^{+}$; or $1.25 \mu \mathrm{l}$ of $\mathrm{PE}-\mathrm{CD}^{+}$, $1.25 \mu \mathrm{l}$ of APC-CD $122^{+}$, and $1 \mu \mathrm{l} \mathrm{FITC}-\gamma \delta \mathrm{T}^{+}$. For the determination of Treg, the surface antigen of $\mathrm{CD} 4^{+}$was labeled first and intracellular staining with PE-Foxp $3^{+}$was performed after fixation and permeabilization. Following the incubations, the cells were washed twice with PBS and resuspended in PBS. The percentages of lymphocytes were analyzed by flow cytometry (Beckman Coulter CytoFlex S).

2.8. Measurement of Serum Cytokines by ELISA. At the end of the experiment, as stated above, all mice were anesthetized with an intraperitoneal injection of sodium pentobarbital $(45 \mathrm{mg} / \mathrm{kg})$. Blood was collected from the angular vein of the eyes of the anesthetized mice. Serum was obtained after centrifugation of blood at $3600 \mathrm{rpm}$ for 10 minutes at $4^{\circ} \mathrm{C}$. Cytokine (TNF- $\alpha$, IL-2, IL-6, and IL-10) levels in the serum were measured using commercial ELISA kits, according to the manufacturer's instructions.

2.9. Statistical Analysis. The results are expressed as mean \pm standard deviation (SD). A one-way analysis of variance (ANOVA) followed by Bonferroni test was used for multiple comparisons between various groups. Differences between groups with $P<0.05$ are considered statistically significant.

\section{Results}

3.1. TLC Analysis of STHJ Extract. Astragaloside IV is the dominant component of SHTJ. In the chromatogram, the STHJ sample and the standard appeared in corresponding positions and showed spots of the same color (Figure 1).

3.2. Effect of STHJ on the Spleen and Thymus Indices in CTXTreated Mice. To investigate the immune regulatory effects of STHJ, low and high doses of STHJ were orally administered to CTX-induced immunosuppressed mice for 30 consecutive days. Compared to the control group, the spleen and thymus indices decreased significantly in the CTX-induced model group $(P<0.01$, Figure 2$)$. In contrast, the spleen and thymus indices were significantly higher in both STHJ and Bailing groups than that in the model group. These data demonstrate that STHJ had a significant protective effect on the reduction of spleen and thymus indices by CTX.

3.3. Effect of STHJ on NK Cells in CTX-Treated Mice. NK cells are important components of the innate immune system and are involved in a variety of diseases, including autoimmune diseases. In this study, CTX injection significantly inhibited the percentage of NK cells in splenocytes of mice $(P<0.01$, Figure 3). In comparison with those in CTX-treated mice, increased NK cell percentages were observed in splenocytes isolated from mice treated with different concentrations of STHJ. A more pronounced effect was observed in the highdose STHJ group $(P<0.01)$.

\subsection{Influence of STHJ on T Cells in CTX-Treated Mice.} Treatment with CTX significantly inhibited the percentage of $\mathrm{CD} 4^{+}$T cells and increased the percentage of $\mathrm{CD} 8^{+} \mathrm{T}$ cells $(P<0.01$, Figures 4(a) and 4(b)). Compared to CTX treatment alone (model group), the administration of low-dose STHJ showed no significant effects on the percentage of $\mathrm{CD}^{+}$or $\mathrm{CD}^{+}{ }^{\mathrm{T}}$ cells, but the high-dose STHJ and Bailing significantly increased the percentage of $\mathrm{CD} 4^{+} \mathrm{T}$ cells and decreased the percentage of $\mathrm{CD}^{+} \mathrm{T}$ cells. In addition, the ratio of $\mathrm{CD}^{+} / \mathrm{CD}^{+} \mathrm{T}$ cells was significantly increased in the high-dose STHJ group and the Bailing group as compared to the CTX treatment only model group.

3.5. Effect of STHJ on T Lymphoid Subpopulations in CTXTreated Mice. During immune homeostasis, T lymphoid subpopulations play a key role in modulating immune status. In recent years, several $\mathrm{T}$ lymphoid subpopulations have been identified and studied. In this study, we detected the percentages of Treg, $\gamma \delta \mathrm{T}, \mathrm{CD} 8^{+} \mathrm{CD} 122^{+} \mathrm{T}$, and NKT cells in the spleen. Compared to normal control mice, CTX treatment elicited a marked increase in the proportion of several inhibitory $\mathrm{T}$ cells $(P<0.01$, Figures 5(a)-5(d)). Compared to CTX-treated mice, neither low- nor high-dose STHJ had any significant influence on Treg cells 

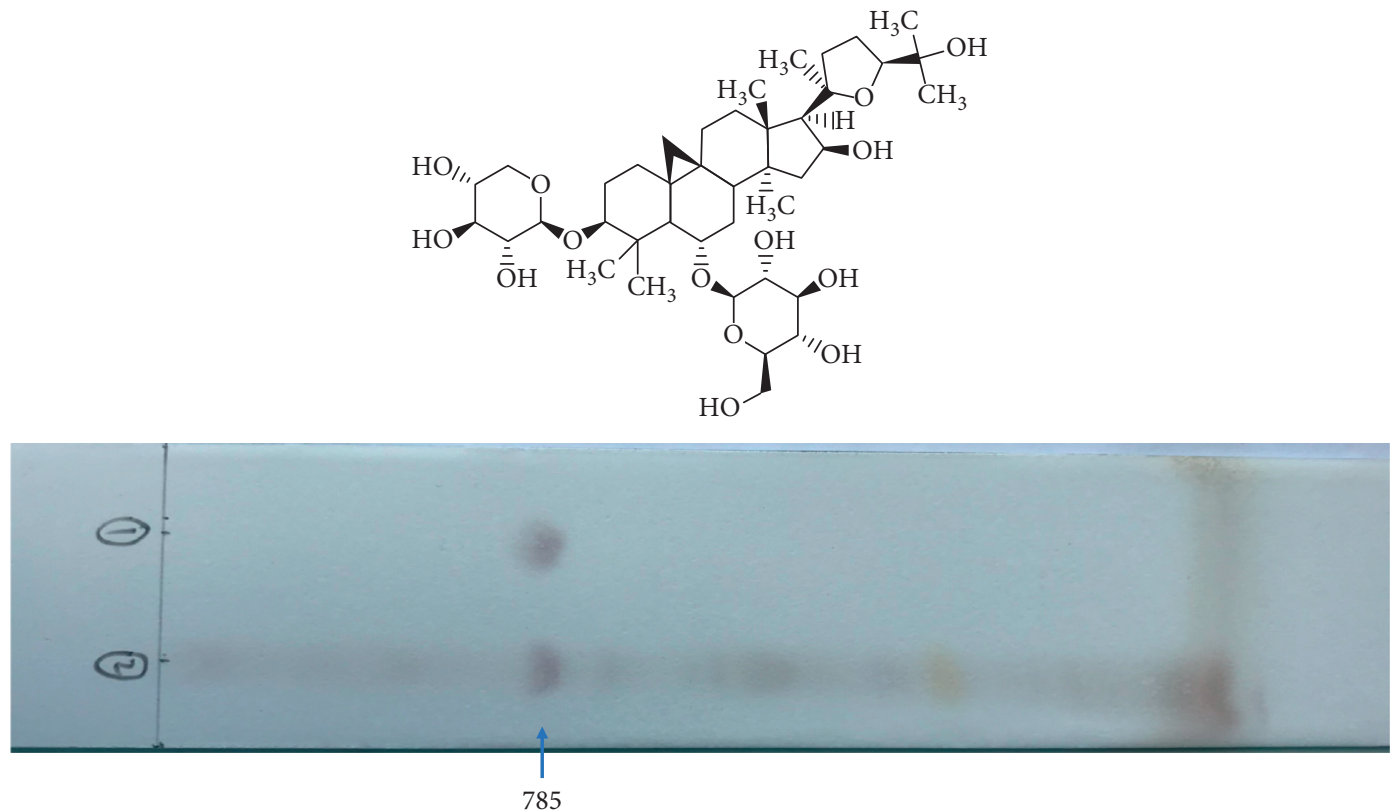

FIGURE 1: Thin-layer chromatogram (TLC) of the extraction solutions of the standard (Astragaloside IV) [1] and the mixture of traditional Chinese medicines, Fufang Shatai Heji (STHJ) [2].

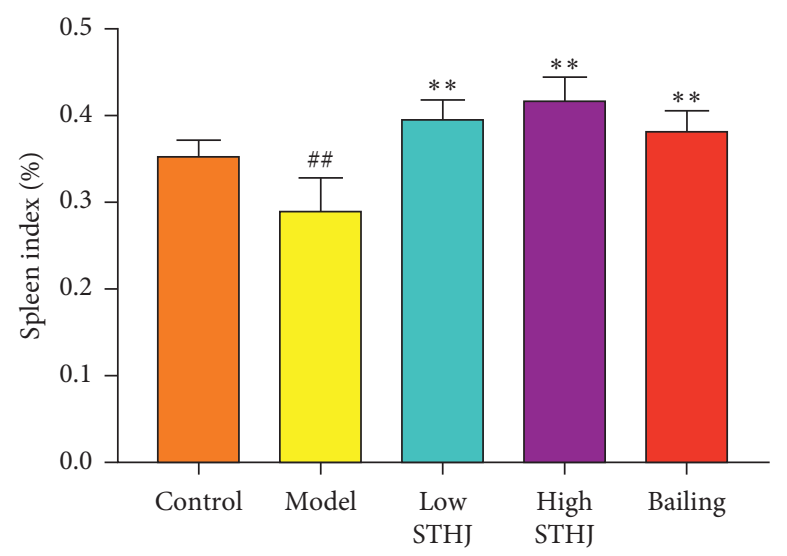

(a)

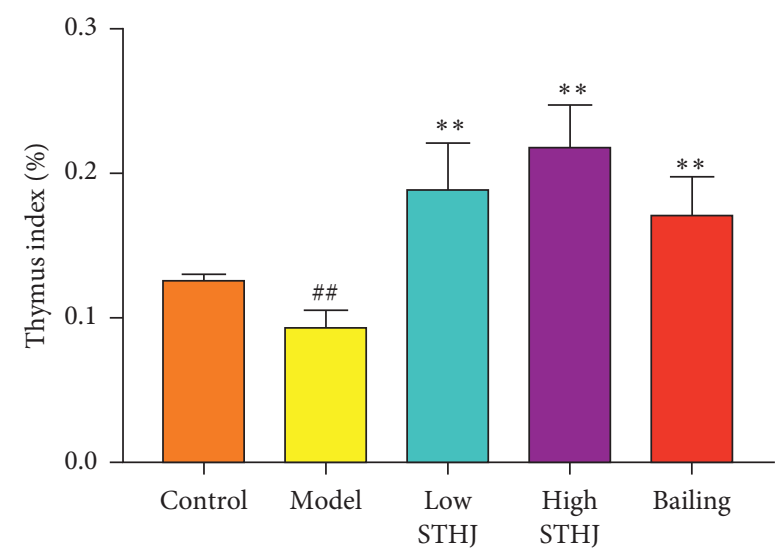

(b)

FIgUre 2: Effect of the mixture of traditional Chinese medicines, Fufang Shatai Heji (STHJ), on the indices of immune organs in cyclophosphamide- (CTX-) treated mice. Sixty mice were randomly assigned into five groups of 12 mice. One group was used as the normal control group, and the others were intraperitoneally injected with CTX $(80 \mathrm{mg} / \mathrm{kg} / \mathrm{d})$ for three consecutive days. Animals in the model group were treated with PBS. The remaining three groups were infused by oral gavage once a day for 30 days with low STHJ (10 ml/kg), high STHJ $(20 \mathrm{ml} / \mathrm{kg})$, and the Bailing group $(1.2 \mathrm{~g} / \mathrm{kg})$. (a) Spleen index and (b) thymus index. All data are expressed as mean \pm standard deviation (SD) $(n=12) .{ }^{\# \#} P<0.01$ vs. control group; ${ }^{* *} P<0.01$ vs. model group.

(Figure 5(a)), but Bailing treatment significantly suppressed the proportion of Treg cells $(P<0.05)$. STHJ in both lowand high-dose groups showed a remarkable downregulation in the percentage of $\gamma \delta \mathrm{T}$ cells $(P<0.05$, Figure 5(b)). In contrast, Bailing showed no significant effect on $\gamma \delta \mathrm{T}$ cells. Treatment with STHJ significantly downregulated the percentage of $\mathrm{CD}^{+} \mathrm{CD} 122^{+} \mathrm{T}$ cells; this effect was more pronounced in the high-dose STHJ group $(P<0.01$, Figure 5(c)). However, Bailing had no significant effect on $\mathrm{CD} 8^{+} \mathrm{CD} 122^{+} \mathrm{T}$ cells. Treatment with STHJ or Bailing significantly downregulated the percentage of NKT cells; this effect was especially pronounced in the high-dose STHJ group $(P<0.01$, Figure 5(d)).

3.6. Effect of STHJ on B Cells in CTX-Treated Mice. $B$ cells and their antibodies are important factors in humoral immunity and the immune response. CTX injections significantly inhibited $B$ cells in the splenocytes of mice $(P<0.01$, Figure 6). Compared to CTX-treated mice, the 


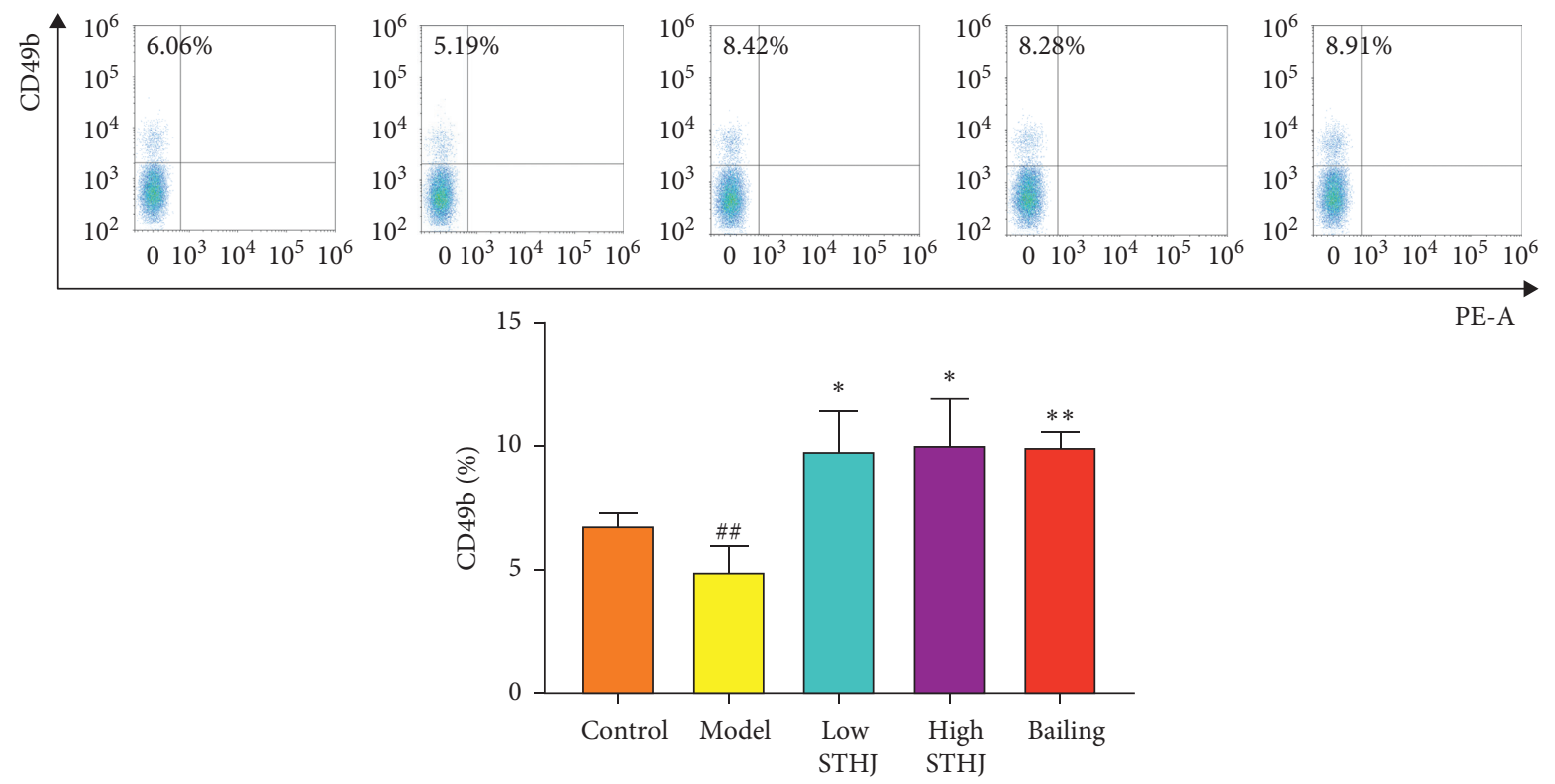

FIGURE 3: Influence of the mixture of traditional Chinese medicines, Fufang Shatai Heji (STHJ), on natural killer (NK) cells in cyclophosphamide- (CTX-) treated mice. NK cells were labeled with CD49b. STHJ significantly enhanced the activity of NK cells without dose dependence. All data are expressed as mean \pm standard deviation $(\mathrm{SD})(n=12)$. ${ }^{\# \#} P<0.01$ vs. control group; ${ }^{* *} P<0.01$ vs. model group.
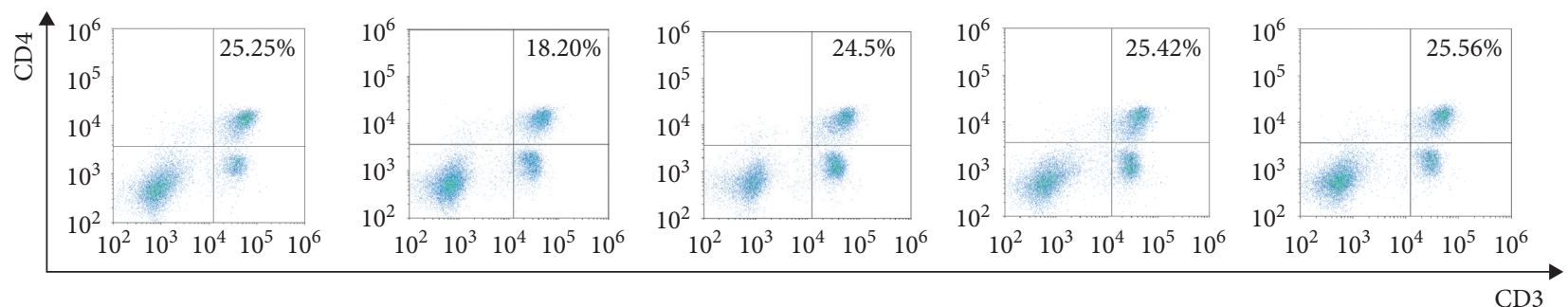

(a)
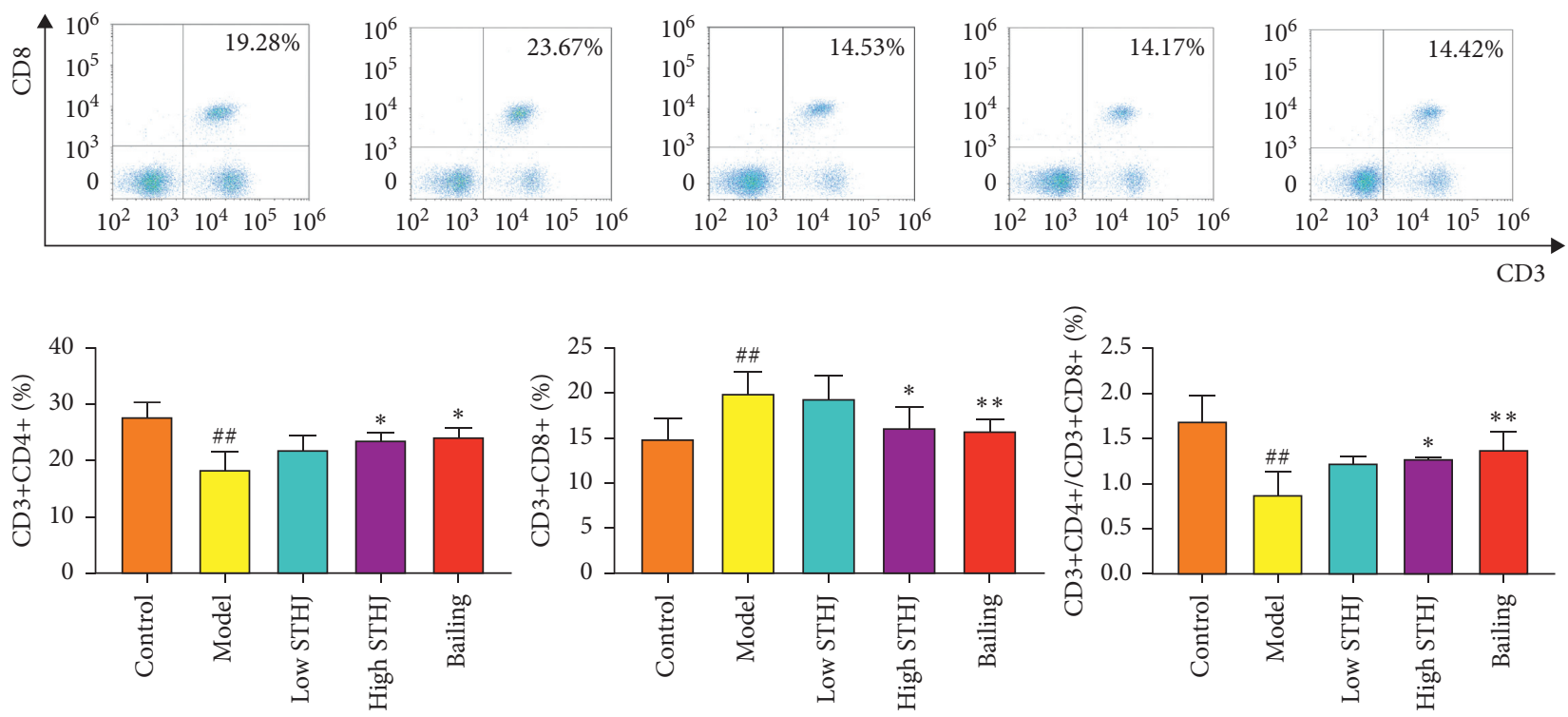

(b)

Figure 4: Influence of the mixture of traditional Chinese medicines, Fufang Shatai Heji (STHJ), on T cells in cyclophosphamide- (CTX-) treated mice. (a, b) The high-dose of STHJ significantly altered the activity of $\mathrm{CD}^{+}{ }^{+} \mathrm{T}$ and $\mathrm{CD} 8^{+} \mathrm{T}$ cells. All data are expressed as mean \pm standard deviation (SD) $(n=12)$. ${ }^{\# \#} P<0.01$ vs. control group; ${ }^{* *} P<0.01$ vs. model group. 

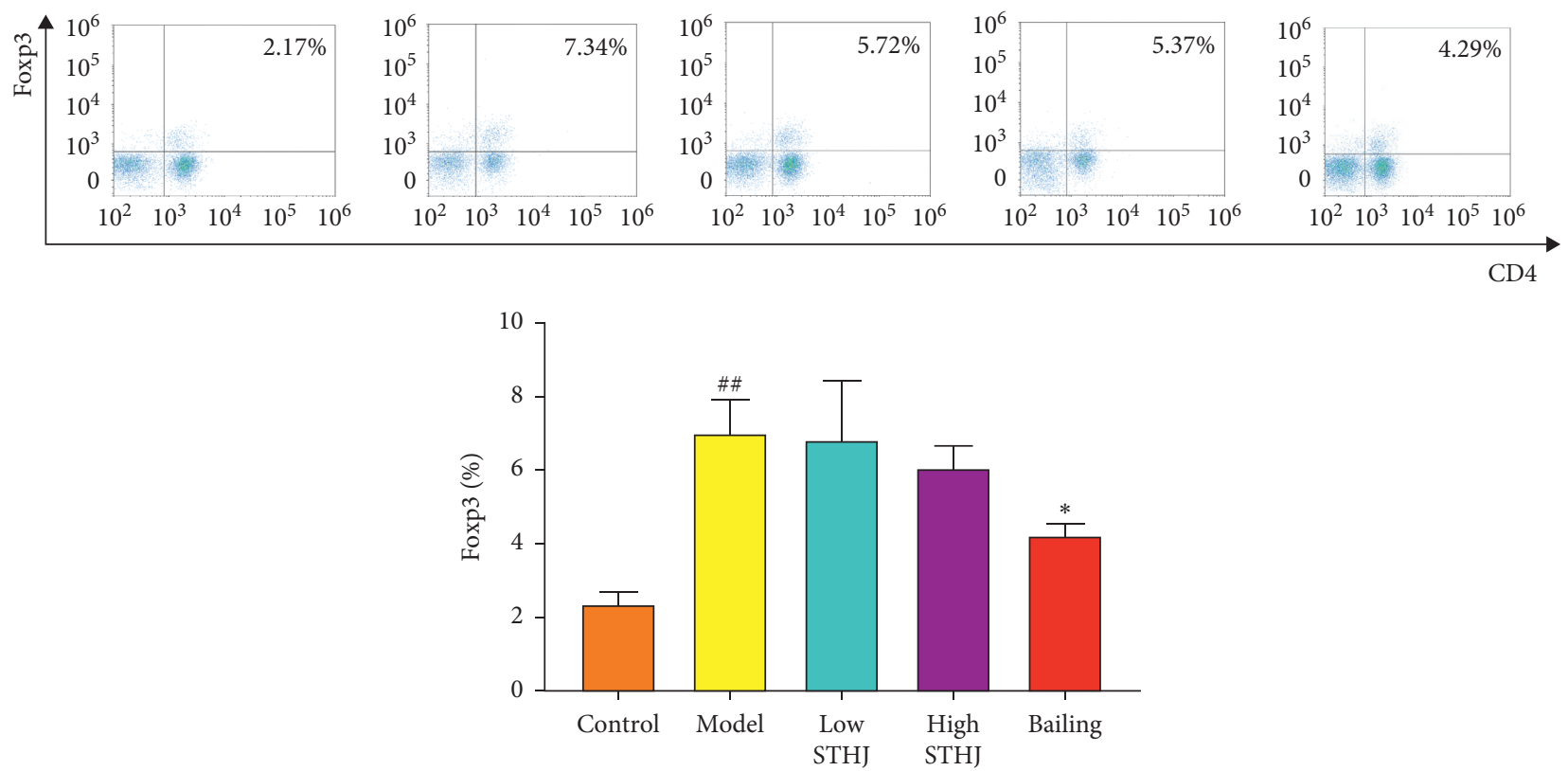

(a)
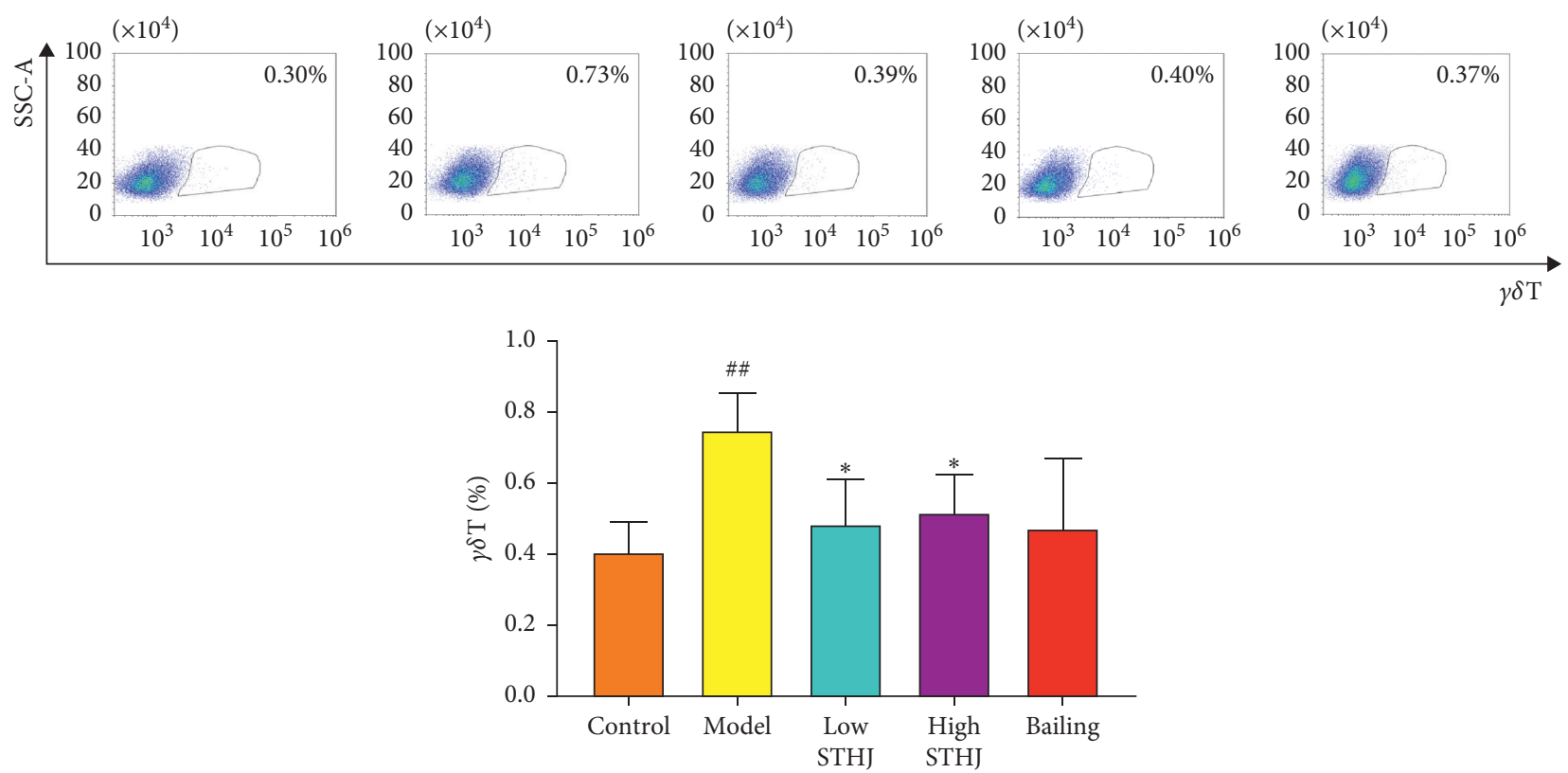

(b)

Figure 5: Continued. 

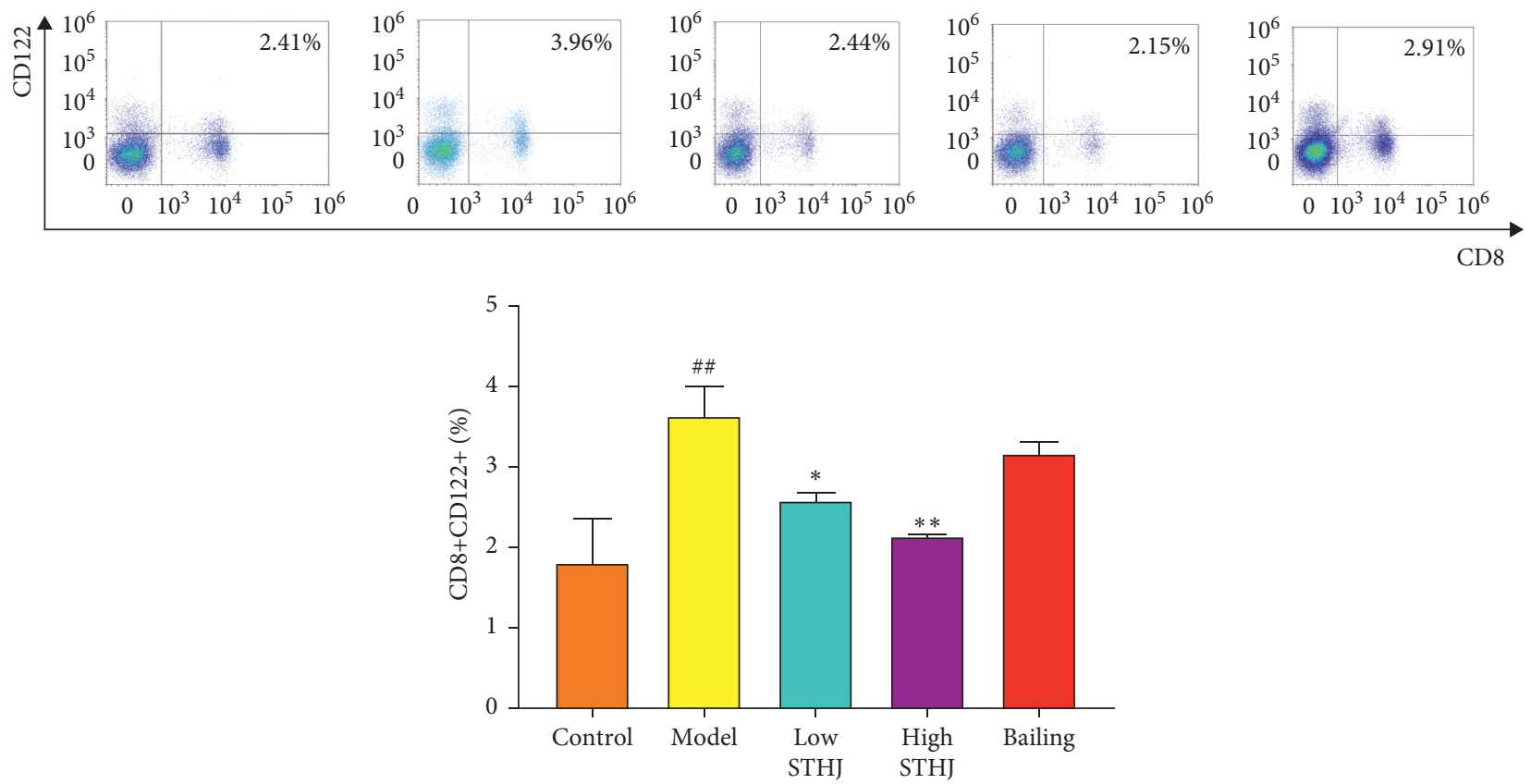

(c)
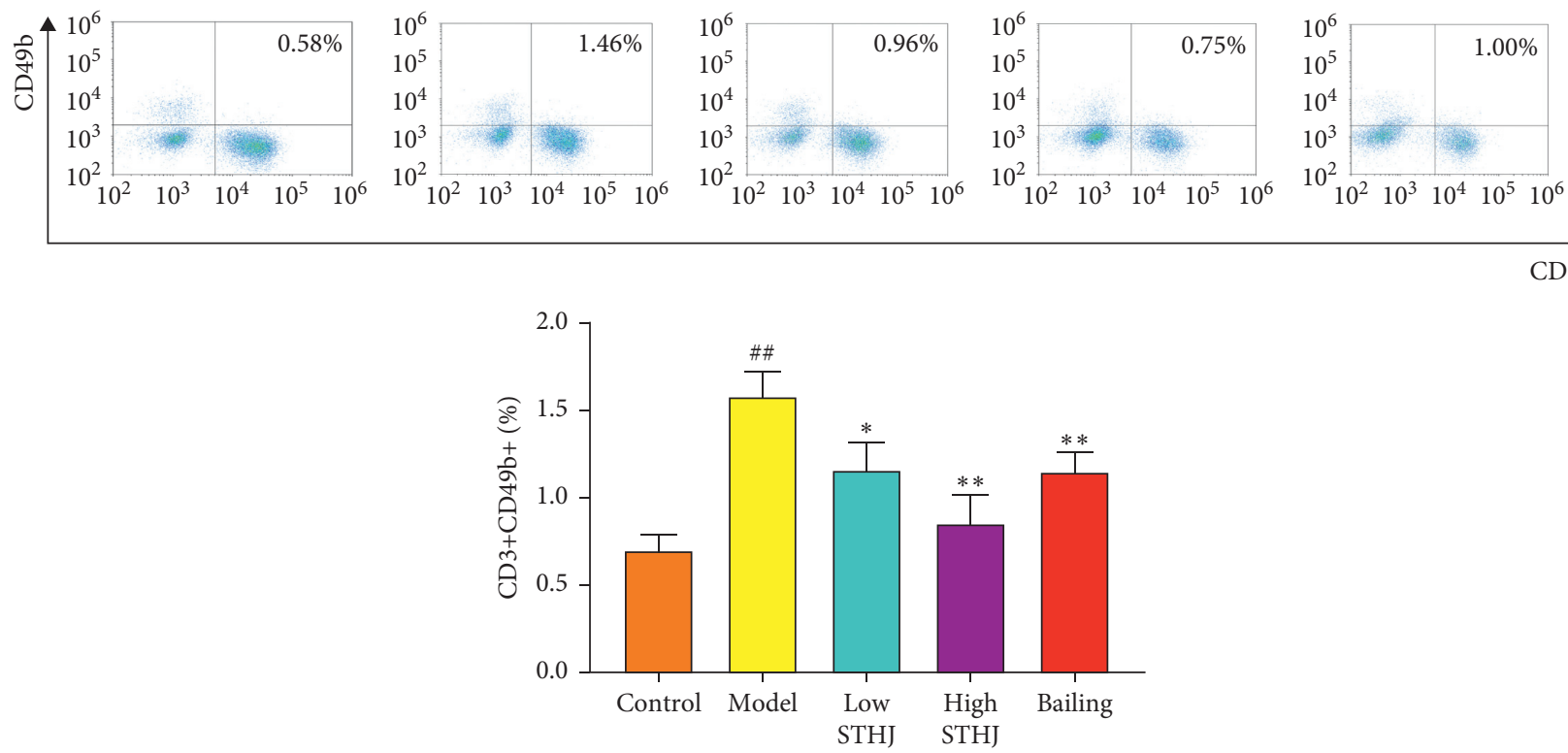

(d)

Figure 5: Effect of the mixture of traditional Chinese medicines, Fufang Shatai Heji (STHJ), on inhibitory T cells in cyclophosphamide(CTX-) treated mice. (a) Treg cells were labeled with $\mathrm{CD}^{+}{ }^{+} \mathrm{Foxp}^{+}$; STHJ had no significant effect on Treg cells. (b) At all doses, STHJ produced a remarkable downregulation of $\gamma \delta \mathrm{T}$ cell activities. (c) STHJ significantly downregulated the activities of CD $8^{+} \mathrm{CD} 122^{+} \mathrm{T}$ and its effect on $\mathrm{CD}^{+} \mathrm{CD} 122^{+} \mathrm{T}$ was dose-dependent. (d) Natural killer T (NKT) cells were labeled with CD ${ }^{+} \mathrm{CD} 49 \mathrm{~b}^{+}$. STHJ significantly inhibited the activity of NKT cells, and this effect was especially pronounced in the high-dose STHJ group. All data are expressed as mean \pm standard deviation (SD) $(n=12) .{ }^{\# \#} P<0.01$ vs. control group; ${ }^{* *} P<0.01$ vs. model group.

percentage of B cells was not altered in the low-dose STHJ group, but was significantly increased in the high-dose STHJ group or Bailing group $(P<0.01)$.

\subsection{Effect of STHJ on Serum Cytokine Levels in CTX-Treated} Mice. Compared to those in the normal control group, serum levels of TNF- $\alpha$, IL-2, and IL- 6 decreased significantly while the levels of IL-10 increased significantly in CTXtreated mice (Figure 7). With STHJ or Bailing treatments, IL-2 and IL-6 levels were markedly upregulated $(P<0.05$ or $P<0.01)$. Treatment with STHJ or Bailing significantly downregulated IL-10 levels in serum $(P<0.05$ or $P<0.01)$. High-dose STHJ induced a significant increase in serum 

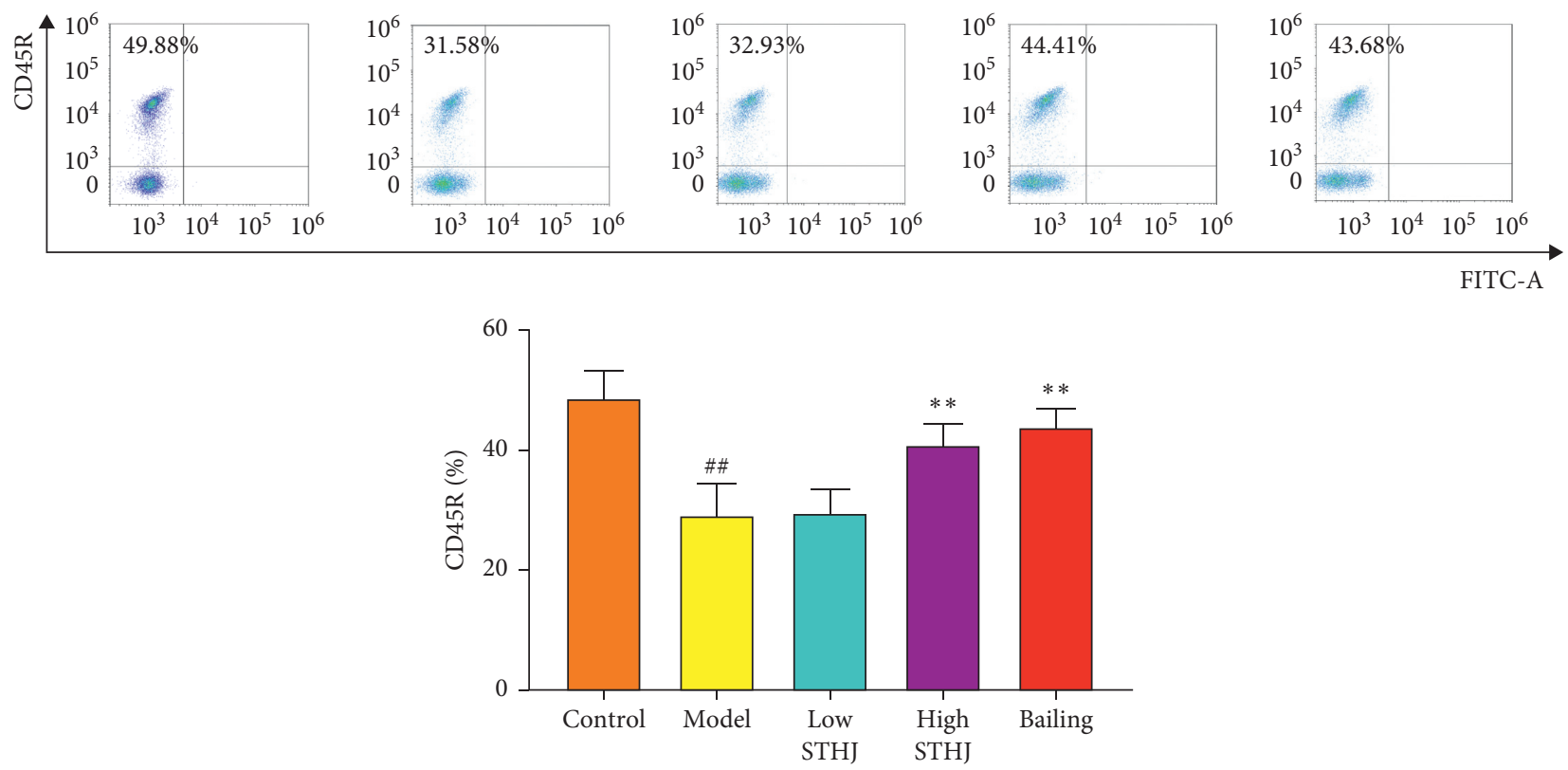

FIgURE 6: Effect of the mixture of traditional Chinese medicines, Fufang Shatai Heji (STHJ), on B cells in cyclophosphamide- (CTX-) treated mice. B cells were labeled with CD45R. High-dose STHJ significantly enhanced the activity of B cells. All data are expressed as mean \pm standard deviation (SD) $(n=12)$. ${ }^{\# \#} P<0.01$ vs. control group; ${ }^{* *} P<0.01$ vs. model group.

levels of TNF- $\alpha$, but Bailing failed to produce any significant effect on TNF- $\alpha$ levels.

\section{Discussion}

CTX and glucocorticoids are two of the most commonly used immunosuppressive drugs in animal studies. Although CTX is a drug primarily used to treat tumors, it has recently been shown to have strong immunosuppressive effects [12]. Glucocorticoids exert inhibitory effects on various immune processes and are, thus, used as antiallergic or anti-inflammatory drugs [13]. Although both CTX and glucocorticoids have immunosuppressive effects, glucocorticoids show no significant effects on B cells. On the other hand, CTX is an efficient drug to induce long-term immunosuppression. Therefore, the CTX-induced immunosuppression mouse model is a suitable model for evaluating the immunomodulatory effects of drugs [2]. Bailing capsule is obtained by fermentation of artificially cultivated fungal strains. It is an asexual type of Cordyceps sinensis, which has similar chemical composition to the natural form. The ingredients of Bailing capsule mainly include adenosine, a variety of amino acids, a variety of vitamins, and trace elements; it can be used as a substitute for natural Cordyceps. Recent studies have shown that Bailing capsule has the effect of increasing immune function [14]. Due to its good immune enhancement, Bailing capsule was used as a positive control drug in this study.

The spleen and thymus are important immune organs where lymphocytes differentiate, mature, and initiate immune responses. The functional state of immune organs directly affects the immune function in the body. When the body is immunocompromised, the spleen and thymus shrink. We found that STHJ significantly increased spleen and thymus indices of immunosuppressed mice, indicating that STHJ has certain immune enhancement functions. To investigate the mechanisms associated with this increase, we conducted a more in-depth in vivo study on the effects of STHJ on lymphocytes and inflammatory factors.

Immunity plays a very important role in the body against disease, mainly comprised of innate and adaptive immunities. The innate immune response is the initial line of defense for the body and is nonspecific. Innate immune cells primarily include phagocytic cells, dendritic cells, and NK cells. NK cells act principally through their secreted cytokines and their natural toxicity to target cells [15-17]. For example, TNF- $\alpha$ and IL-10 secreted by NK cells could regulate immune function by affecting downstream immune responses $[17,18]$. TNF- $\alpha$ is a potent proinflammatory cytokine that is involved in many immune functions. For these reasons, anti-TNF- $\alpha$ antibodies are used to treat some autoimmune diseases, such as rheumatoid arthritis (RA) [19]. In addition, several studies have found that NK cells inhibit the function of $\mathrm{CD}^{+}$and $\mathrm{CD}^{+}$T cells [20-23] while Treg cells in turn inhibit the activity of NK cells [24]. Thus, NK cells are thoroughly involved in immune regulation. Using immunosuppression models, Jang et al. reported a significant reduction in the number of NK cells in the spleen of CTX-treated mice [25]. In this study, the proportion of NK cells in the CTX-treated mice was also reduced, and this effect was reversed by STHJ treatment at both low and high doses. Therefore, we conclude that NK cells are sensitive to STHJ and are involved in the mechanism of STHJ-enhanced immune functions.

The adaptive immune system is mainly composed of $\mathrm{T}$ and B lymphocytes that mediate cellular and humoral immunity, respectively. The main types of T cells are $\mathrm{CD}^{+}$and $\mathrm{CD}^{+} \mathrm{T}$ lymphocytes, which are the key regulators in 


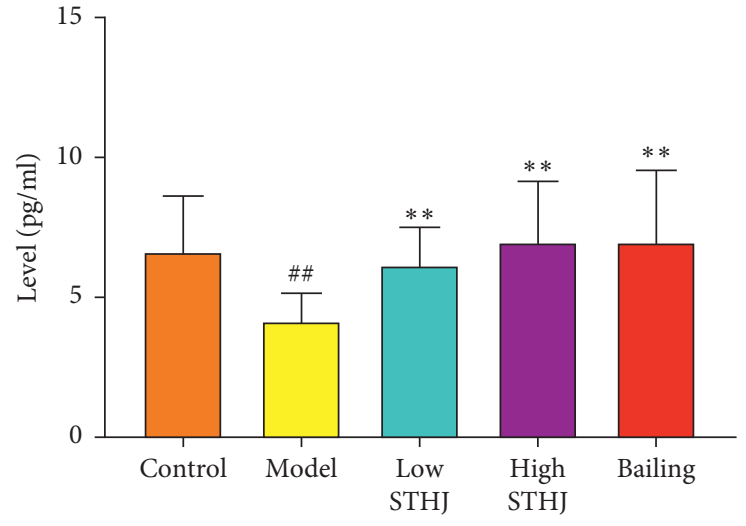

IL-2

(a)

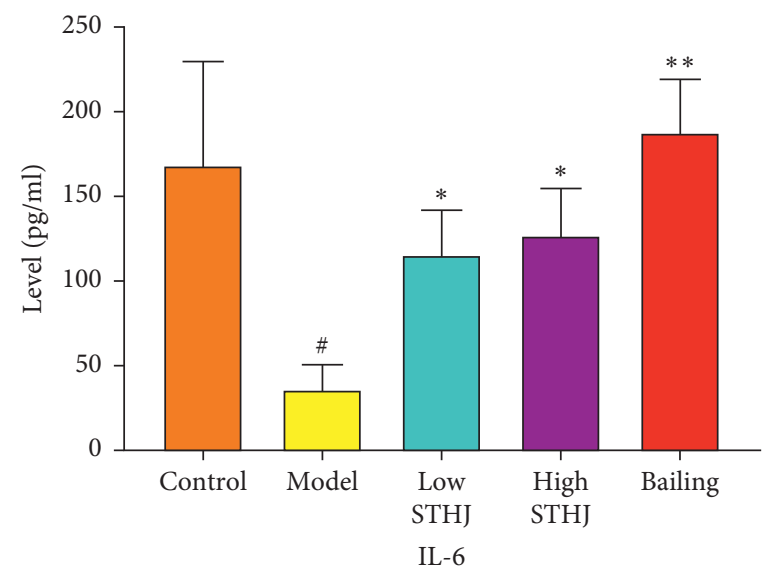

(c)

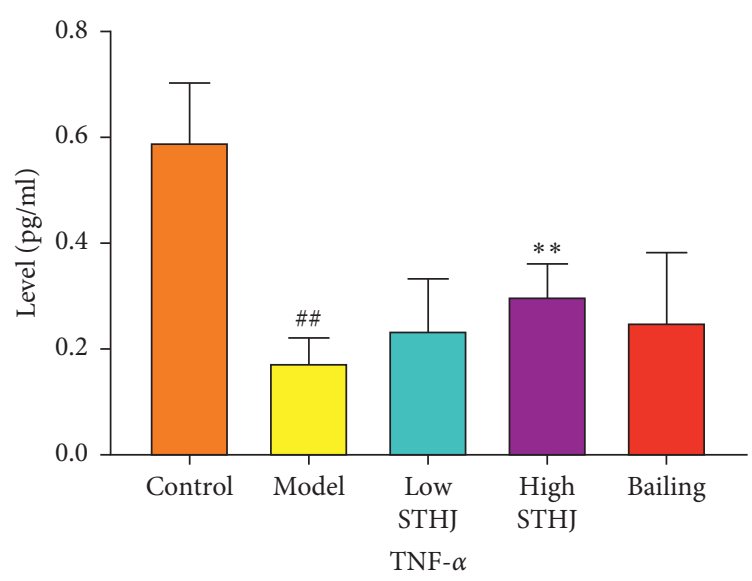

(b)

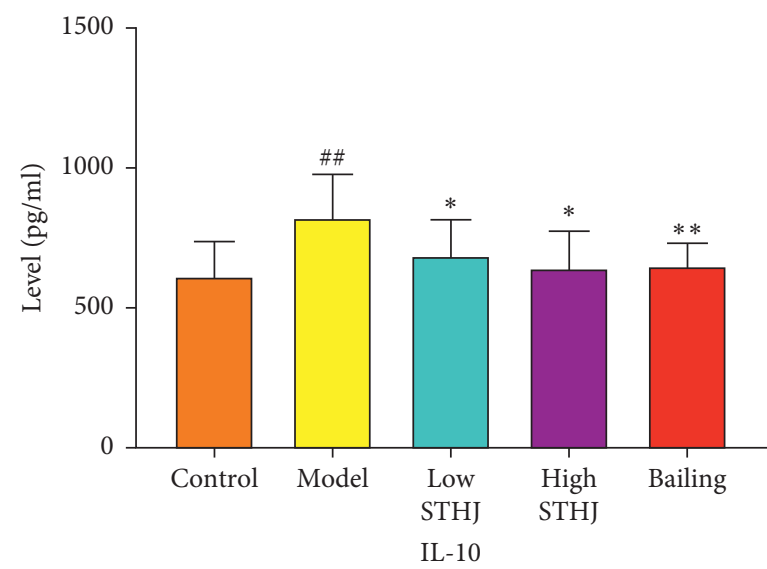

(d)

FIGURE 7: Effect of the mixture of traditional Chinese medicines, Fufang Shatai Heji (STHJ), on the serum levels of interleukin-2 (IL-2), IL-6, IL-10, and tumor necrosis factor- $\alpha$ (TNF- $\alpha$ ) in cyclophosphamide- (CTX-) treated mice. All data are expressed as mean \pm standard deviation (SD) $(n=12) .{ }^{\# \#} P<0.01$ vs. control group; ${ }^{* *} P<0.01$ vs. model group.

adaptive immune responses [26]. An imbalance in the ratio of $\mathrm{CD}^{+} \mathrm{T}$ lymphocytes to $\mathrm{CD} 8^{+} \mathrm{T}$ lymphocytes may lead to the growth of autoimmune diseases. Here, we first examined the effect of STHJ on total T lymphocytes. Using the CTXinduced immunosuppression mouse model, the results in our study showed that the $\mathrm{CD} 4^{+} / \mathrm{CD}^{+} \mathrm{T}$ cell ratio was significantly reduced in the CTX-treated mice, which is consistent with that reported by Yu et al. [3]. Interestingly, we found that high dose of STHJ significantly inhibited the proliferation of $\mathrm{CD} 8^{+} \mathrm{T}$ cells and increased the number of $\mathrm{CD} 4^{+} \mathrm{T}$ cells, resulting in an increased $\mathrm{CD} 4^{+} / \mathrm{CD}^{+}$ratio. It has been reported that Radix Pseudostellariae raised the $\mathrm{CD}^{+} / \mathrm{CD}^{+}$ratio by increasing the percentage of $\mathrm{CD} 4^{+}$ $\mathrm{T}$ lymphocytes while decreasing the percentage of $\mathrm{CD}^{+}$ T lymphocytes [27]. Hence, it is conceivable that Radix Pseudostellariae in STHJ may contribute to the effect on the levels of $\mathrm{CD} 4^{+}$and $\mathrm{CD} 8^{+} \mathrm{T}$ cells and regulate their imbalance in CTX-induced immunosuppressed mice.

To further clarify the influence of STHJ on $\mathrm{T}$ lymphocytes, we investigated the effects of STHJ on multiple $\mathrm{T}$ lymphoid subpopulations, for example, Treg, $\mathrm{CD} 8^{+} \mathrm{CD} 122^{+} \mathrm{T}, \gamma \delta \mathrm{T}$, and NKT cells. Regulatory T cells are a subtype of $\mathrm{CD}^{+}{ }^{+} \mathrm{T}$ cells that play key roles in the development of autoimmune and other diseases [28]. Previous studies found that the function of Treg cells is regulated by several inflammatory factors, such as IL-2, IL-6, and IL-10. Among these, IL-2, a pleiotropic cytokine produced after antigen activation, is involved in the generation of immune responses. IL-2 activates Treg cells and is used to treat autoimmune diseases caused by Treg cell defects [29]. IL-6 is a cytokine secreted by many types of cells, such as T cells and $\mathrm{B}$ cells, and is essential for maintaining the immune system. Studies have found that IL-6 can interfere with the function of Treg cells and prevent Th17 cells from transforming into Treg cells [30]. IL-10 is a pleiotropic cytokine mainly secreted by macrophages and plays crucial functions in the initiation of autoimmune diseases. It has been shown that IL-10 activated Treg cells, leading to the inhibition of Th17 cell function [31]. In our experiments, we found that the expression of IL- 2 and IL- 6 in the CTX-treated mice was significantly lower than those in the control group, while the expression of IL-10 and Treg was significantly increased. Similarly, serum levels of IL-2, IL-6, and IL-10 in the CTXtreated mice were significantly different from those of the 
STHJ-treated mice, but there was no compelling difference in Tregs. Therefore, the induction of Treg cells by IL- 2 may counteract the effects of IL-6 and IL-10 on Treg cells. Our results are in agreement with previous results from Wang et al. [32]. Using immunosuppression models, they found that the proportion of Treg cells in the model group was significantly higher than that in the control group. Moreover, treatment with Radix Astragali markedly upregulated the level of Treg cells. Besides Radix Astragali, other ingredients in STHJ may reduce its effects on Treg by downregulating the number of Treg cells.

Accumulating evidence suggests that $\mathrm{CD}^{+} \mathrm{CD} 122^{+}$ $\mathrm{T}$ cells are a type of Tregs that inhibit autoimmunity and allogeneic immunity. It was found that high levels of $\mathrm{CD}^{+} \mathrm{CD} 122^{+}$Tregs significantly enhanced the clinical symptoms of experimental autoimmune encephalomyelitis (EAE) [33]. It has also been reported that administration of $\mathrm{CD}^{+}{ }^{+} \mathrm{CD} 122^{+} \mathrm{T}$ cells increased the proportion of autoimmune Graves' hyperthyroidism in a mouse model [34]. In addition, the adoptive transfer of $\mathrm{CD}^{+} \mathrm{CD} 122^{+}$Tregs may prolong the survival of allografts [35]. Therefore, $\mathrm{CD}^{+} \mathrm{CD} 122^{+}$Tregs are thought to be widely involved in immune regulation. Importantly, it was reported that native $\mathrm{CD}^{+} \mathrm{CD} 122^{+}$Tregs are more effective than $\mathrm{CD} 4^{+} \mathrm{CD} 25^{+}$ Tregs to induce immunosuppression [36]. In the present studies, the proportion of $\mathrm{CD} 8{ }^{+} \mathrm{CD} 122^{+} \mathrm{T}$ cells in the CTXtreated mice was remarkably higher than that in the control mice, suggesting that $\mathrm{CD} 8^{+} \mathrm{CD} 122^{+} \mathrm{T}$ cells play a role in immunosuppressive states. Although STHJ had no significant effect on Treg cells in the immunosuppression model, it significantly inhibited the expression of $\mathrm{CD}^{+} \mathrm{CD} 122^{+}$ $\mathrm{T}$ cells, especially at high doses. These results suggest that $\mathrm{STHJ}$ has a more pronounced effect on $\mathrm{CD}^{+} \mathrm{CD} 122^{+} \mathrm{T}$ cells than on Treg cells.

$\gamma \delta \mathrm{T}$ cells are a subset of $\mathrm{T}$ cells that have traditionally been considered to mediate cytotoxic functions. However, recent studies suggested that they also play a negative role in the regulation of immune function. Several studies have demonstrated a certain degree of transcriptional overlap between conventional Tregs and inhibitory $\gamma \delta \mathrm{T}$ cells. However, the regulatory mechanisms of the inhibitory function of these two cell types have not been fully defined [37]. In our experiments, we found that the proportion of $\gamma \delta \mathrm{T}$ cells in the CTX-treated mice was very high, suggesting that $\gamma \delta \mathrm{T}$ cells play an important role in suppressing the immune function. Although STHJ had no significant effect on Treg cells in the CTX-treated mice, we found that it significantly reduced the expression level of $\gamma \delta \mathrm{T}$ cells in this group. Therefore, the activity of $\gamma \delta \mathrm{T}$ cells appears to play important roles in mediating the immune-enhancing functions of STHJ in the immunosuppressive state.

NKT cells are a group of T cell lineages with immunomodulatory activity, mainly composed of type I and type II NKT cells [38]. Both subtypes have a regulatory role in autoimmune diseases. Type I NKT cells are implicated in systemic lupus erythematosus (SLE) and influence the pathogenicity of hepatitis. In contrast, type II NKT cells confer protection in both diseases [39]. Therefore, NKT cells may have both immune enhancement and immunosuppressive effects. When stimulated by an antigen, NKT cells can produce a range of cytokines, including IL-2, IL-10, and TNF- $\alpha$ [40, 41]. These cytokines regulate immunity by activating T cells, B cells, and other immune cells. For instance, IL-2 secreted by NKT can induce $\mathrm{CD} 4^{+} \mathrm{T}$ cells to differentiate into Th2 cells and inhibit Treg cells $[42,43]$. Activated NKT cells can trigger the production of IgM and IgG antibodies from B cells by secreting IL-21 [44, 45]. Thus, the immunomodulatory effects of NKT cells are complex. In our experiments, the proportion of NKT cells in the CTX-treated mice was significantly higher than that in the control mice, whereas STHJ significantly inhibited the expression of NKT cells, especially at high dose. Therefore, the inhibitory effect of STHJ on NKT cells plays an important role in enhancing the immune function. Moreover, NKT cells may eliminate the effect of STHJ on Treg cells in an immunosuppressive state by inhibiting the activity of Treg cells.

Apart from T lymphocytes, B lymphocytes also play an important role in autoimmune diseases. They participate in humoral immune regulation by secreting a large number of specific antibodies. Additionally, B lymphocytes regulate other cells by producing many inflammatory cytokines, such as IL-2, IL-6, IL-10, and TNF- $\alpha$. It has been shown that B cells aggravated EAE conditions by producing IL-6 [46]. Meanwhile, it was reported that IL-10-producing B cells inhibit autoimmune diseases by activating Tregs, thereby downregulating the production of proinflammatory cytokines [47-51]. Thus, defects in B lymphocyte functions can also cause a variety of autoimmune diseases. In this study, the proportion of B cells in the CTX-treated mice was significantly higher than that in the control mice. Interestingly, low-dose STHJ had no effect on the number of B cells, but high-dose STHJ significantly increased the proportion of B cells. This means that B cells may be less sensitive to STHJ, even though they play an important role in the mechanism of STHJ in enhancing immune functions.

\section{Conclusion}

In summary, we report that the effect of STHJ on the immune system is complex because it induces changes in the expression of various lymphocytes and inflammatory factors and also modulates interactions among these factors. Based on the results of this study, we conclude that STHJ plays a positive role in immune functions, especially at high dose. We have shown that STHJ could reverse CTX-induced immunosuppression and, therefore, our experimental results provide evidence of the immunopotentiating effects of STHJ. In a future study, we would like to investigate the effects of STHJ on a number of diseases caused by low immunity or immune disorder, such as Sjögren's syndrome.

\section{Abbreviations}

CTX: Cyclophosphamide

TCM: Traditional Chinese medicine

STHJ: Fufang Shatai Heji

NK: Natural killer cells

RA: Rheumatoid arthritis 
EAE: Experimental autoimmune encephalomyelitis

SLE: Systemic lupus erythematosus

Tregs: T regulatory cells.

\section{Data Availability}

The data used to support the findings of this study are available from the corresponding author upon request.

\section{Disclosure}

The funding bodies play no role in the design of the study and collection, analysis, and interpretation of data and in writing the manuscript.

\section{Conflicts of Interest}

The authors declare that they have no conflicts of interest.

\section{Authors' Contributions}

KF and TW participated in research design; KF, YL, JW, BX, and QW conducted experiments; KF, JL, JZ, QC, and TW contributed new reagents or analytic tools; KF, YL, and QC performed data analysis; KF, QC, and TW wrote or contributed to the writing of the manuscript; all authors approved the final version to be published. KF and YL contributed equally to this work.

\section{Acknowledgments}

This work was supported by the National Natural Science Foundation of China (Grants 81874011, 81572104, and 81301531 (to T.-Y. W.)). This work was also partially supported by the Shanghai Municipal Science and Technology Commission (Innovation Grant 18140903502 (to T.-Y. W.)).

\section{References}

[1] E. Vargas, S. Apewokin, and R. Madan, "Role of the leukocyte response in normal and immunocompromised host after Clostridium difficile infection," Anaerobe, vol. 45, pp. 101-105, 2017.

[2] X.-H. Huyan, Y.-P. Lin, T. Gao, R.-Y. Chen, and Y.-M. Fan, "Immunosuppressive effect of cyclophosphamide on white blood cells and lymphocyte subpopulations from peripheral blood of Balb/c mice," International Immunopharmacology, vol. 11, no. 9, pp. 1293-1297, 2011.

[3] Q. Yu, S.-P. Nie, J.-Q. Wang et al., "Chemoprotective effects of Ganoderma atrum polysaccharide in cyclophosphamide-induced mice," International Journal of Biological Macromolecules, vol. 64, pp. 395-401, 2014.

[4] M. J. Qin, Y. B. Yu, W. Z. Huang, Y. Zhu, L. Yan, and S. B. Pu, "Quality assay of Pseudostellaria heterophylla collected from different regions," Research and Practice on Chinese Medicines, vol. 5, pp. 29-32, 2005.

[5] B. X. Du, M. R. Xiang, Y. P. Fu, J. Zhang, H. Q. Jiang, and R. Rong, "Investigation of isolation, purificatio, structural identification and in vitro immunological function of polysaccharides in glehniae radix," Chinese Journal of Experimental Traditional Medical Formulae, vol. 24, pp. 27-31, 2018.
[6] C.-p. Wan, L.-x. Gao, L.-f. Hou et al., “Astragaloside II triggers T cell activation through regulation of CD45 protein tyrosine phosphatase activity," Acta Pharmacologica Sinica, vol. 34, no. 4, pp. 522-530, 2013.

[7] Y. M. Ding, B. P. Hu, and Y. Q. Guo, "Preliminary study on the treatment of Sjogren's syndrome with self-made SS syrup," Shanghai Journal of Stomatology, vol. 3, pp. 143-144, 1995.

[8] C. Y. Yu and B. P. Hu, "Clinical study of SS syrup in treating xerostomia," Chinese Journal of Integrated Traditional and Western Medicine, vol. 25, pp. 899-901, 2005.

[9] X. Y. Yang, "Experimental study on the effect of Radix Adenophorae on T lymphocyte subsets in immunosuppressive C57BL/6J mice," Journal of Taishan Medical College, vol. 4, pp. 247-249, 2012.

[10] J. K. Wang, J. Zheng, Y. J. Shen, and R. G. Wang, "Effect of total extract of Radix Pseudostellariae on immune function and nucleic acid content of thymus and spleen in cyclophosphamide-treated animals," Pharmacology and Clinics of Chinese Materia Medica, vol. 6, pp. 16-18, 1996.

[11] J. J. Shi, B. Shi, and M. S. Miao, "Effect of Astragalus polysaccharide on immunological function of immunosuppressive mice induced by cyclophosphamide," Acta Chinese Medicine, vol. 31, pp. 243-246, 2016.

[12] M. E. de Jonge, A. D. R. Huitema, S. Rodenhuis, and J. H. Beijnen, "Clinical pharmacokinetics of cyclophosphamide," Clinical Pharmacokinetics, vol. 44, no. 11, pp. 1135-1164, 2005.

[13] A. M. Isidori, M. A. Venneri, C. Graziadio et al., "Effect of once-daily, modified-release hydrocortisone versus standard glucocorticoid therapy on metabolism and innate immunity in patients with adrenal insufficiency (DREAM): a singleblind, randomised controlled trial," The Lancet Diabetes \& Endocrinology, vol. 6, no. 3, pp. 173-185, 2018.

[14] H. J. Xu and S. Y. Li, "Pharmacological effects of Bailing capsule and its application in lung disease research," China Journal of Chinese Materia Medica, vol. 35, pp. 2777-2781, 2010.

[15] H.-G. Ljunggren and K.-J. Malmberg, "Prospects for the use of NK cells in immunotherapy of human cancer," Nature Reviews Immunology, vol. 7, no. 5, pp. 329-339, 2007.

[16] A. R. French and W. M. Yokoyama, "Natural killer cells and viral infections," Current Opinion in Immunology, vol. 15, no. 1, pp. 45-51, 2003.

[17] E. Vivier, E. Tomasello, M. Baratin, T. Walzer, and S. Ugolini, "Functions of natural killer cells," Nature Immunology, vol. 9, no. 5, pp. 503-510, 2008.

[18] S.-H. Lee, K.-S. Kim, N. Fodil-Cornu, S. M. Vidal, and C. A. Biron, "Activating receptors promote NK cell expansion for maintenance, IL-10 production, and CD8 T cell regulation during viral infection," The Journal of Experimental Medicine, vol. 206, no. 10, pp. 2235-2251, 2009.

[19] H. Zelová and J. Hošek, "TNF- $\alpha$ signalling and inflammation: interactions between old acquaintances," Inflammation Research, vol. 62, no. 7, pp. 641-651, 2013.

[20] K. Soderquest, T. Walzer, B. Zafirova et al., "Cutting edge: $\mathrm{CD}^{+} \mathrm{T}$ cell priming in the absence of NK cells leads to enhanced memory responses," The Journal of Immunology, vol. 186, no. 6, pp. 3304-3308, 2011.

[21] P. A. Lang, K. S. Lang, H. C. Xu et al., "Natural killer cell activation enhances immune pathology and promotes chronic infection by limiting $\mathrm{CD}^{+}$T-cell immunity," Proceedings of the National Academy of Sciences, vol. 109, no. 4, pp. 1210$1215,2012$.

[22] S. N. Waggoner, M. Cornberg, L. K. Selin, and R. M. Welsh, "Natural killer cells act as rheostats modulating antiviral T cells," Nature, vol. 481, no. 7381, pp. 394-398, 2011. 
[23] S. N. Waggoner, R. T. Taniguchi, P. A. Mathew, V. Kumar, and R. M. Welsh, "Absence of mouse 2B4 promotes NK cellmediated killing of activated $\mathrm{CD}^{+} \mathrm{T}$ cells, leading to prolonged viral persistence and altered pathogenesis," Journal of Clinical Investigation, vol. 120, no. 6, pp. 1925-1938, 2010.

[24] Y. Kerdiles, S. Ugolini, and E. Vivier, "T cell regulation of natural killer cells," The Journal of Experimental Medicine, vol. 210, no. 6, pp. 1065-1068, 2013.

[25] S.-E. Jang, E.-H. Joh, Y.-T. Ahn, C.-S. Huh, M. J. Han, and D.-H. Kim, "Lactobacillus caseiHY7213 ameliorates cyclophosphamide-induced immunosuppression in mice by activating NK, cytotoxic $\mathrm{t}$ cells and macrophages," Immunopharmacology and Immunotoxicology, vol. 35, no. 3, pp. 396-402, 2013.

[26] S. L. Swain, K. K. McKinstry, and T. M. Strutt, "Expanding roles for $\mathrm{CD}^{+}$T cells in immunity to viruses," Nature Reviews Immunology, vol. 12, no. 2, pp. 136-148, 2012.

[27] R. Sheng, X. Xu, Q. Tang et al., "Polysaccharide of radix pseudostellariae improves chronic fatigue syndrome induced by poly I:C in mice," Evidence-Based Complementary and Alternative Medicine, vol. 2011, Article ID 840516, 9 pages, 2011.

[28] S. Z. Josefowicz, L.-F. Lu, and A. Y. Rudensky, "Regulatory T cells: mechanisms of differentiation and function," Annual Review of Immunology, vol. 30, no. 1, pp. 531-564, 2012.

[29] N. Arenas-Ramirez, J. Woytschak, and O. Boyman, "Interleukin-2: biology, design and application," Trends in Immunology, vol. 36, no. 12, pp. 763-777, 2015.

[30] C. A. Hunter and S. A. Jones, "IL-6 as a keystone cytokine in health and disease," Nature Immunology, vol. 16, no. 5, pp. 448-457, 2015.

[31] A. Chaudhry, R. M. Samstein, P. Treuting et al., "Interleukin10 signaling in regulatory T cells is required for suppression of Th17 cell-mediated inflammation," Immunity, vol. 34, no. 4, pp. 566-578, 2011.

[32] X. M. Wang, T. Y. Jia, B. Guan et al., "Effects of Astragalus Polysaccharide on $\mathrm{CD} 4^{+} \mathrm{CD} 25^{+}$Treg cells and Th17 cells in immunesuppressed mice," Natural Product Research and Development, vol. 27, pp. 153-157, 2015.

[33] P. Yu, R. N. Bamford, and T. A. Waldmann, "IL-15-dependent $\mathrm{CD}^{+} \mathrm{CD} 122^{+} \mathrm{T}$ cells ameliorate experimental autoimmune encephalomyelitis by modulating IL-17 production by $\mathrm{CD}^{+}$T cells," European Journal of Immunology, vol. 44, no. 11, pp. 3330-3341, 2014.

[34] O. Saitoh, N. Abiru, M. Nakahara, and Y. Nagayama, " $\mathrm{CD} 8{ }^{+} \mathrm{CD} 122^{+} \mathrm{T}$ cells, a newly identified regulatory $\mathrm{T}$ subset, negatively regulate Graves' hyperthyroidism in a Murine model," Endocrinology, vol. 148, no. 12, pp. 6040-6046, 2007.

[35] Z. Dai, S. Zhang, Q. Xie et al., "Natural CD8 ${ }^{+} \mathrm{CD} 122^{+}$T cells are more potent in suppression of allograft rejection than $\mathrm{CD} 4{ }^{+} \mathrm{CD} 25^{+}$regulatory T cells," American Journal of Transplantation, vol. 14, no. 1, pp. 39-48, 2014.

[36] J. Liu, D. Chen, G. D. Nie, and Z. Dai, "CD8 ${ }^{+} \mathrm{CD} 122^{+}$T-cells: a newly emerging regulator with central memory cell phenotypes," Frontiers in Immunology, vol. 6, p. 494, 2015.

[37] K. K. Payne, "Lymphocyte-mediated immune regulation in health and disease: the Treg and $\gamma \delta \mathrm{T}$ cell co-conspiracy," Immunological Investigations, vol. 45, no. 8, pp. 767-775, 2016.

[38] A. Bendelac, P. B. Savage, and L. Teyton, "The biology of NKT cells," Annual Review of Immunology, vol. 25, no. 1, pp. 297-336, 2007.
[39] V. Kumar and T. L. Delovitch, "Different subsets of natural killer T cells may vary in their roles in health and disease," Immunology, vol. 142, no. 3, pp. 321-336, 2014.

[40] M. Terabe and J. A. Berzofsky, "Chapter 8 the role of NKT cells in tumor immunity," Advances in Cancer Research, vol. 101, pp. 277-348, 2008.

[41] V. V. Parekh, L. Wu, D. Olivares-Villagómez, K. T. Wilson, and L. Van Kaer, "Activated invariant NKT cells control central nervous system autoimmunity in a mechanism that involves myeloid-derived suppressor cells," The Journal of Immunology, vol. 190, no. 5, pp. 1948-1960, 2013.

[42] R. A. Seder, W. E. Paul, M. M. Davis, and B. Fazekas de St Groth, "The presence of interleukin 4 during in vitro priming determines the lymphokine-producing potential of $\mathrm{CD}^{+}$ T cells from T cell receptor transgenic mice," The Journal of Experimental Medicine, vol. 176, no. 4, pp. 1091-1098, 1992.

[43] J. L. Matsuda, L. Gapin, N. Fazilleau, K. Warren, O. V. Naidenko, and M. Kronenberg, "Natural killer T cells reactive to a single glycolipid exhibit a highly diverse $\mathrm{T}$ cell receptor repertoire and small clone size," Proceedings of the National Academy of Sciences, vol. 98, no. 22, pp. 1263612641, 2001.

[44] P. Barral, J. Eckl-Dorna, N. E. Harwood et al., "B cell receptormediated uptake of CD1d-restricted antigen augments antibody responses by recruiting invariant NKT cell help in vivo," Proceedings of the National Academy of Sciences, vol. 105, no. 24, pp. 8345-8350, 2008.

[45] E. A. Leadbetter, M. Brigl, P. Illarionov et al., "NK T cells provide lipid antigen-specific cognate help for B cells," Proceedings of the National Academy of Sciences, vol. 105, no. 24, pp. 8339-8344, 2008.

[46] T. A. Barr, P. Shen, S. Brown et al., "B cell depletion therapy ameliorates autoimmune disease through ablation of IL-6producing B cells," The Journal of Experimental Medicine, vol. 209, no. 5, pp. 1001-1010, 2012.

[47] Y. Iwata, T. Matsushita, M. Horikawa et al., "Characterization of a rare IL-10-competent B-cell subset in humans that parallels mouse regulatory B10 cells," Blood, vol. 117, no. 2, pp. 530-541, 2011.

[48] P. Serra and P. Santamaria, “To 'B' regulated: B cells as members of the regulatory workforce," Trends in Immunology, vol. 27, no. 1, pp. 7-10, 2006.

[49] M. Saraiva and A. O'Garra, "The regulation of IL-10 production by immune cells," Nature Reviews Immunology, vol. 10, no. 3, pp. 170-181, 2010.

[50] J.-D. Bouaziz, S. Calbo, M. Maho-Vaillant et al., "IL-10 produced by activated human B cells regulates $\mathrm{CD} 4^{+} \mathrm{T}$-cell activation in vitro," European Journal of Immunology, vol. 40, no. 10, pp. 2686-2691, 2010.

[51] T. Musette, M. Horikawa, Y. Iwata, and T. F. Tedder, "Regulatory B cells (B10 cells) and regulatory T cells have independent roles in controlling experimental autoimmune encephalomyelitis initiation and late-phase immunopathogenesis," The Journal of Immunology, vol. 185, no. 4, pp. 2240-2252, 2010. 